TAPROBANICA, ISSN 1800-427X. May, 2021. Vol. 10, No. 01: pp. 61-63, pl. 12.

(C) Research Center for Climate Change and Department of Biology, Faculty of Mathematics \& Natural Sciences, University of Indonesia, Depok 16424, INDONESIA.

http://www.taprobanica.org

https://doi.org/10.47605/tapro.v10i1.250

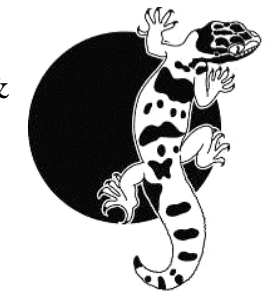

\section{Biofluorescence in the Sri Lankan House Gecko (Hemidactylus parvimaculatus)}

In just the last five years, biofluorescence has been recorded in a growing number of reptiles (Gruber \& Sparks 2015, Prötzel et al. 2018, 2021, Sloggett 2018, Jeng 2019, Seiko \& Terai 2019, Eto 2020, Top et al. 2020). In lizards, ultraviolet-induced visible fluorescence is known to occur in several genera of chameleons (Prötzel et al. 2018) as well as the nocturnal gekkonids Pachydactylus rangei (Prötzel et al. 2021), Cyrtodactylus quadrivirgatus (Sloggett 2018), C. baluensis (Jeng 2019) and Chondrodactylus bibronii (Top et al. 2020). Under ultraviolet (UV) light, these gekkonids display varying degrees of bonebased fluorescence of the anterior skull and various skeletal elements including the vertebral column, limb bones, pelvis, lower jaw and toe articulations (Sloggett 2018, Jeng 2019, Top et al. 2020, Prötzel et al. 2021). In P. rangei, fluorescence also occurs in the iridophores of the skin (Prötzel et al. 2021). With more than 1,300 extant species recognized within the Gekkonidae (Uetz et al. 2020) including many with similar morphologies, body sizes, ecologies and habits as these biofluorescent species, this research prompted investigation of whether UV-induced fluorescence occurs in additional taxa within this family.

The genus Hemidactylus is comprised of more than 160 species (Uetz et al. 2020) of small nocturnal geckos that are endemic to tropical and subtropical environments of the Old World (Carranza \& Arnold 2006). Aided by various anthropogenic activities, several species have also appreciably expanded their distributions and become naturalized in many new parts of the world (Lever 2003, Kraus 2009). Aptly known as "house geckos", these species frequently inhabit anthropogenic environments, favoring the exteriors of buildings and other man-made structures where they congregate around lights at night to hunt insects
(Perry \& Fisher 2006). Although many biological aspects of the group have been studied, as far as I could determine, investigations into the potential for biofluorescence in Hemidactylus have not been carried out to date.

Similar in body size, coloration and ecology to many of its congeners, $H$. parvimaculatus is naturally distributed in Southern Asia including extreme southern India, Sri Lanka and some adjacent island groups (Wickramasinghe \& Somaweera 2003, Bauer et al. 2010b) where it occurs in forests, rock outcroppings, cultivated lands and anthropogenic environments (de Silva et al. 2000, Karunarathna \& Amarasinghe 2010, 2011). Additionally, introduced populations of $H$. parvimaculatus have become established in Bangkok, Thailand (Cota \& Hakim 2011), the southeastern United States (Heckard et al. 2013, Pellecchia et al. 2019), and the Australian external territory of the Cocos (Keeling) Islands (Wilson \& Swan 2021). In August 2020, twelve specimens of $H$. parvimaculatus from an introduced population in Belle Chasse, Louisiana, USA $\left(9.85832^{\circ} \mathrm{N}, 89.99059^{\circ} \mathrm{W}\right.$; WGS 84; see Pellecchia et al. 2019) were collected from the brick exterior walls of a private residence and examined for evidence of biofluorescence. Subjects represented both sexes and all age classes (juveniles, subadults, adults) and ranged in snout-vent length from 23 to 51 $\mathrm{mm}$. In a dark room, each specimen was tested for fluorescence by shining a 3-watt, $365 \mathrm{~nm}$ LED UV torch (model UV301D; Shenzhen LIGHTFE Lighting Co., Ltd., Shenzhen, China) over its body while in hand from a distance of $\sim 50 \mathrm{~cm}$.

All examined specimens fluoresced a brilliant blueish color under $365 \mathrm{~nm}$ UV light. Putative bone-based fluorescence was visible in most of the skull, the vertebral column, limb bones, elbow and knee joints, and toe articulations (Fig. 1A1-2). Ventrally, the lower jaw also fluoresced vividly (Fig. 1B1-2). No appreciable differences were observed in the color, intensity or distribution of fluorescence 
between sexes, but smaller individuals exhibited a greater overall intensity of fluorescence than subadults and adults (Fig. 1C1-2). An additional twenty $H$. parvimaculatus representing all age classes fluoresced brilliantly when spotlighted on the exterior brick walls of the residence with the same UV torch from a distance of $\sim 100 \mathrm{~cm}$.

These findings represent the first record of UV-induced visible fluorescence in the genus Hemidactylus as well as the first case of biofluorescence in a South Asian gecko. Since many other species of Hemidactylus have body sizes, coloration, ecologies and habits similar to $H$. parvimaculatus including $H$. turcicus, which has also been observed to fluoresce under UV light (RWM, pers. obs.), fluorescence may be present at least to some extent in all members of the genus. From a much broader perspective, similar patterns of putative bone-based fluorescence now documented in several disparate gecko genera (Sloggett 2018, Jeng 2019, Top et al. 2020, Prötzel et al. 2021, this study) suggests that bone-based biofluorescence may be widespread in the Gekkonidae. Further research including an extensive sampling of taxa is needed to shed light on just how common this phenomenon is in the group as well as provide clues for understanding its origins and evolution.

It is unclear what the ecological relevance of fluorescence may be for $H$. parvimaculatus. Similar fluorescent emission patterns observed in Chondrodactylus bibronii and Cyrtodactylus quadrivirgatus have been anecdotally attributed to intraspecific communicative signaling (Sloggett 2018, Top et al. 2020), where increased conspicuousness via fluorescence could make it easier for conspecifics to locate one another at night or in low visible light environments where the proportion of shorter wavelength ambient light, including UV radiation, is greatest (Lythgoe 1979). At the same time, increased conspicuousness from fluorescence could also increase the risk of predation by species that are visually sensitive to UV-fluorescent tissues. On the other hand, it is also quite possible that bone-based fluorescence in geckos is merely coincidental and an artifact of the inherent fluorescent properties of bone tissue (Bachman \& Ellis 1965) that happens to be visible through the thin and semi-translucent skin of smaller lizard species under strong UV light. Behavioral studies can help determine what role, if any, biofluorescence may play in the ecology of these species.
Finally, the discovery of fluorescence in Hemidactylus parvimaculatus may offer opportunities to develop more effective techniques for surveying this species and other congeners in the field. In particular, UV light could be useful for spotting biofluorescent geckos on dark, mottled or textured backgrounds in anthropogenic environments such as the exterior walls of buildings where obtaining accurate population size estimates at night can be challenging (e.g. Lardner et al. 2015). A pilot study to evaluate the effectiveness of UVemitting LED torches to spotlight for $H$. parvimaculatus around buildings at night is currently planned for the grounds of Audubon Zoo, where the species was first recorded in the United States (Heckard et al. 2013). In addition to anthropogenic structures, cursory tests of this technique in more vegetated landscapes have also shown efficacy in spotlighting $H$. parvimaculatus on vegetation at night, suggesting an even broader potential application of this technique for field surveys.

\section{Acknowledgements}

I thank Laurence Paul for insightful discussions of biofluorescence in reptiles, the Smithsonian Institution Libraries for providing useful literature, and Ruchira Somaweera for useful comments on this manuscript.

\section{Literature Cited}

Bachman, C.H. and E.H. Ellis (1965). Fluorescence of bone. Nature, 206 (4991): $1328-1331$.

Cota, M. and J. Hakim. (2011). Hemidactylus parvimaculatus (Sri Lankan House Gecko). Geographical distribution. Herpetological Review, 42 (2): 241.

de Silva, A., S. Molur, and S. Walker (eds.) (2000). Conservation Assessment and Management Plan, CAMP Report for Amphibians and Selected Taxa of Reptiles of Sri Lanka. Conservation Breeding Specialist Group, Sri Lanka, Colombo: 212pp.

Eto, K. (2020). Limaformosa crossi (Crosse's file snake) and Mehelya poensis (western forest file snake). Coloration / biofluorescence. Herpetological Review, 51 (3): 622-623.

Gruber, D.F. and J.S. Sparks. (2015). First observation of fluorescence in marine turtles. American Museum Novitates, 3845: 1-7.

Heckard, D., A. Kathriner, and A.M. Bauer. (2013). First record of Hemidactylus parvimaculatus Deraniyagala, 1953 from the 


\section{Plate 12}

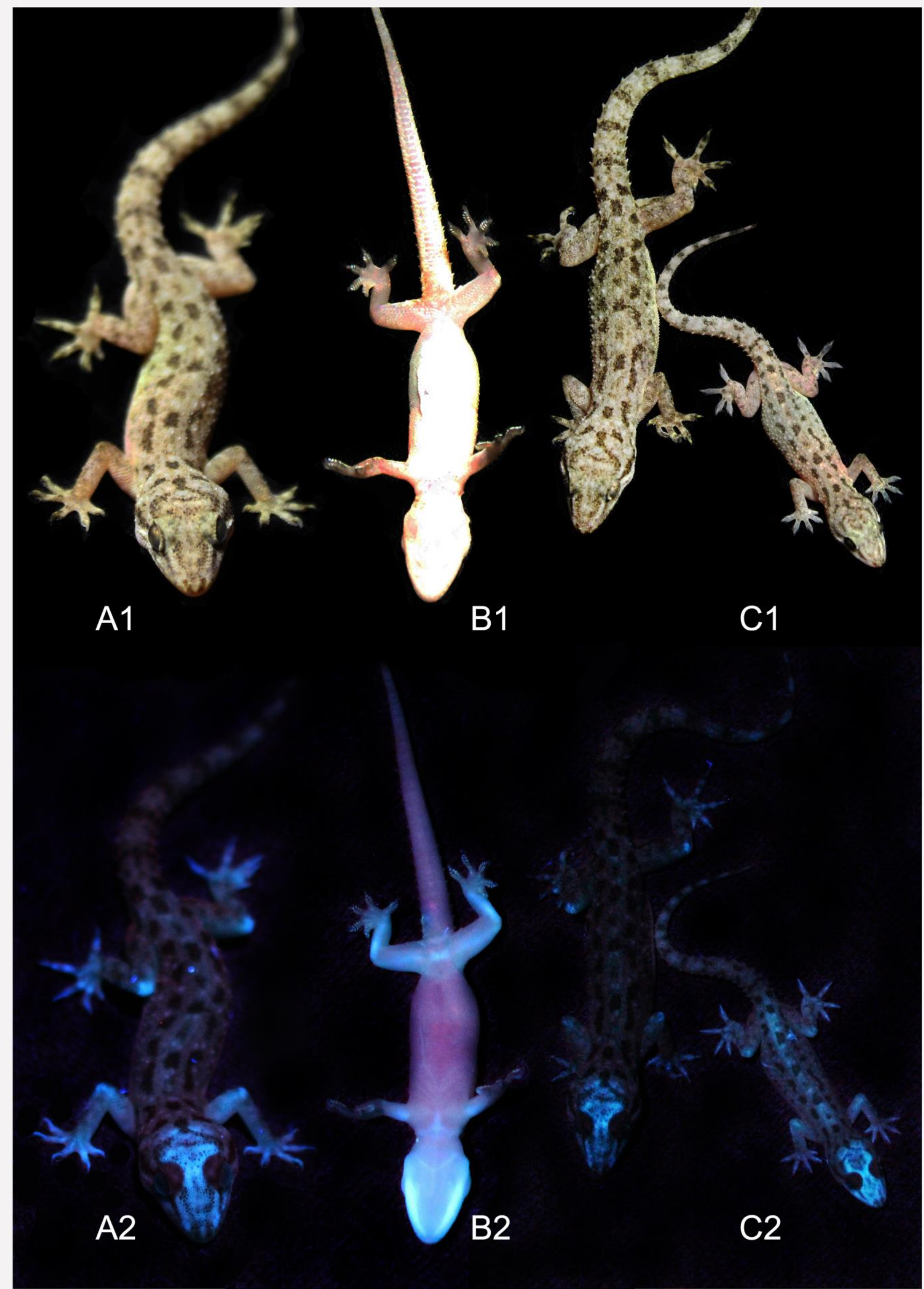

Figure 1. Putative bone-based UV fluorescence in Hemidactylus parvimaculatus: (A) an adult, (B) a sub-adult (note the lower jaw and rear limb bones), and (C) comparison between adult (left) and juvenile (right) 
United States. IRCF Reptiles \& Amphibians, 20 (4): 192-196.

Karunarathna, D.M.S.S. and A.A.T. Amarasinghe (2010). Hemidactylus parvimaculatus Deraniyagala, 1953 (Reptilia: Gekkonidae) feeds on Ramanella variegata (Stoliczka, 1872) (Amphibia: Microhylidae) in Sri Lanka. Taprobanica, 2 (2): 104

Karunarathna, S.D.M.S. and A.A.T. Amarasinghe (2011). A preliminary survey of the reptile fauna in Nilgala forest and its vicinity, Monaragala District, Sri Lanka. Taprobanica, 3 (2): 69-76.

Jeng, M.-L. (2019). Biofluorescence in terrestrial animals, with emphasis on fireflies: a review and field observation In: Suzuki, H. (ed.), Bioluminescence: Analytical applications and basic biology. Intech Open, London: 87-111.

Kraus, F. (2009). Alien Reptiles and Amphibians: A Scientific Compendium and Analysis. Springer, Dordrecht: 569pp.

Lardner, B., G.H. Rodda, A.A.Y. Adams, J.A. Savidge, and R.N. Reed. (2015). Detection rates of geckos in visual surveys: Turning confounding variables into useful knowledge. Journal of Herpetology, 49 (4): 522-532.

Lever, C. (2003). Naturalized Reptiles and Amphibians of the World. Oxford University Press, New York: 318pp.

Lythgoe, J.N. (1979). The Ecology of Vision. Clarendon Press, Oxford: 226pp.

Pellecchia, C.M., B.M. Glorioso, R.W. Mendyk, C.A. Collen et al. (2019). Hemidactylus parvimaculatus (Sri Lankan spotted house gecko). Geographical distribution. Herpetological Review, 50 (3): 525-526.

Perry, G. and R.N. Fisher. (2006). Night lights and reptiles: Observed and potential effects. In: Ecological Consequences of Artificial Night Lighting, Rich, C. and T. Longcore (eds.). Island Press, Washington: 169-191.

Prötzel, D., M. Hess, M. D. Scherz, M. Schwager et al. (2018). Widespread bone-based fluorescence in chameleons. Scientific Reports, 8: 698.

Prötzel, D., M. Heiss, M. Schwager, F. Glaw, and M. D. Sherz. (2021). Neon-green fluorescence in the desert gecko Pachydactylus rangei caused by iridophores. Scientific Reports, 11 (1): $1-10$.

Seiko, T. and Y. Terai. (2019). Fluorescence emission in a marine snake. Galaxea, 21 (1): $7-8$.

Sloggett, J.J. (2018). Field observations of putative bone-based fluorescence in a gecko. Current Zoology, 64 (3): 319-320.
Top, M.M., C.L. Puan, M.-F. Chuang, S.N. Othman, and A. Borzee. (2020). First record of ultraviolet fluorescence in the bent-toed gecko Cyrtodactylus quadrivirgatus Taylor, 1962 (Gekkonidae: Sauria). Herpetology Notes, 13: 211-212.

Uetz, P., P. Freed, and J. Hosek (eds.) (2020). The Reptile Database <www.reptile-database.org> accessed on 28 October 2020.

Wickramasinghe, M. and R. Somaweera. (2003). Distribution and current status of the endemic geckos of Sri Lanka. Gekko, 3 (1): 2-13.

Wilson, S. and G. Swan. (2021). Complete Guide to Reptiles of Australia. New Holland Publishers, Sydney: 572pp.

Submitted: 21 Nov. 2020, Accepted: 5 March 2021 Section Editor: Ruchira Somaweera

Robert W. Mendyk ${ }^{1,2}$

${ }^{1}$ Department of Herpetology, Audubon Zoo, 6500 Magazine St., New Orleans, Louisiana 70118, USA E-mail: rmendyk@auduboninstitute.org

${ }^{2}$ Department of Herpetology, Smithsonian National Zoological Park, 3001 Connecticut Avenue NW, Washington, D.C. 20008, USA 